\title{
LITERARY CULTURES AND PUBLIC OPINION IN THE EARLY MODERN LOW COUNTRIES
}

\author{
Jan Bloemendal and Arjan van Dixhoorn
}

\section{INTRODUCTION: HOOFT AND THE POWER OF SPEECH}

In his Nederlandsche Historiën (Dutch History) of 1642, the Amsterdam man of letters Pieter Corneliszoon Hooft examined the significance of 'the art of rhyming' in the origins of the Dutch Revolt. That art, Hooft tells us, was practised in most towns and many villages of the Low Countries by 'the ablest and liveliest minds' in their chambers of rhetoric. They published poems to 'pass from hand to hand' and staged public performances of farces and serious plays in which they 'showed where everyone's duties lay'. According to Hooft, it was impossible for anyone to compete with 'de scharpheit van een gladde tong' (the sharpness of a honed tongue), which could 'persuade in one hour' and, through the passion of 'the characters', could instantly influence more people than liberally distributed 'handwritten pamphlets or printed books' could ever hope to. Rhetoricians, with their 'freedom of speech', attacked the failings of the 'papists', mocked 'blatant abuses' and fiercely condemned the persecution of heretics. ${ }^{1}$

The recital of rhymes, Hooft wrote, had therefore made a vital contribution to the growth of a critical disposition towards the clergy and towards the persecution of heretics, and as such amounted to a substantial contributing factor in the causes of the Revolt. He gave three reasons for attributing a greater influence to spoken works than to written or printed texts: the physical power of the speaker to persuade, the immediacy of the experience, and the number of people

${ }^{1}$ Hooft, Nederlandsche Historiën, pp. 36-37. See also Waterschoot, 'The rederijkerskamers en de doorbraak van de reformatie in de Zuidelijke Nederlanden', pp. 141-42. The extract (translated into modern Dutch) is also included in Hooft, Nederlandse Historiën, ed. Van Gestel, Grootes and De Jongste, pp. 52-53. 
who could be reached. For contemporary historians writing about the Dutch Republic, the importance of the rhetoricians for the origins of the Revolt was a truism they deployed, among other things, in the defence of the chambers and their public plays against attacks by clergymen of the Reformed Church. ${ }^{2}$

Sixteenth-century political, religious and intellectual authorities were themselves concerned about the persuasive power of songs and poems. Fearing the divisive potential of such works, they developed special censorship rules such as bans on the treatment of certain subjects, the checking of texts prior to performance, and thereafter prosecution and, where deemed necessary, sanctions. ${ }^{3}$

Hooft's belief in the efficacy of performative literature to communicate ideas is at odds with the notion still prevailing today that the printing of books was responsible for an enormous increase in the rapid and extensive dissemination of opinions, and that the Reformation would not have been possible without this revolution in communications. The latter view has been modified substantially in recent years by historians of the Reformation, giving more weight to the spoken word that received so much praise from Hooft for forming a connection between the public and the world of written and printed texts. ${ }^{4}$ Hooft believed that by 1560 the Low Countries had an organized literary life, sustained by cultured minds who criticized frankly the performance of the authorities in public, reminding both citizens and people in positions of power of their responsibilities. The rhetoricians' regional

2 Among those who quote this argument with approval are Geeraerd Brandt in his Historie der Reformatie, I, 229 and Emanuel van Meteren in his Historie der Nederlandscher ende haerder Na-buren Oorlogen ende geschiedenissen, fol. 29r-v. See also for example Waterschoot, 'De rederijkerskamers en de doorbraak van de Reformatie', pp. 151-53.

${ }^{3}$ For the ban on the printed collection of stage offerings for the competition in Ghent in 1539 see Van Bruaene, 'Printing Plays'. For a discussion of the Protestant nature of these plays see: Waite, Reformers on Stage and Ramakers, 'In utramque partem vel in plures'. For the development of the censorship policy with regard to the stage in Holland and Zeeland and the failure of a local commission of theologians established in 1551 for the censoring of plays prior to performance, see Van Dixhoorn, Lustige geesten, p. 324. It is worth adding that the authorities sometimes acted harshly but on other occasions were comparatively mild, and local governments varied in the extent to which they took notice of orders from central government.

${ }^{4}$ The relationship between the spoken, written and printed word outside the world of scholarship has been explored by, for example, Scribner, 'Oral Culture and the Diffusion of Reformation Ideas'; Fox, The Spoken Word, and idem, Oral and Literate Culture in England 1500-1700; and Pettegree, Reformation and the Culture of Persuasion. They emphasize that spoken and performed works were often written down or printed, and printed and written works often read aloud, recited and acted. 
networks are evidence that the literary life of early modern societies helped to create supra-local communities in which, as Hooft saw it, collective opinions were formed which governments had to take into account. ${ }^{5}$ Both the existence of such supra-local vehicles for creating public opinion in a world of performative literature and Hooft's interpretation of their importance seem at first sight to conflict with the view of German sociologist Jürgen Habermas that before 1700 such supra-local communities did not exist, any more than the concept of public opinion existed. ${ }^{6}$

Habermas is relevant here because the model and the criteria he used to explain the development of a modern public sphere, and the place that public opinion occupied in it, have become paradigmatic. Criticism has been brought to bear on certain aspects, and revisions have been proposed, some of which we shall examine later, but the notion that a modern public sphere could develop only with the rise of a critical national press and an informed, engaged and critical national public coming together in nationwide networks of societies, salons, coffee houses, theatres and concert halls is nevertheless broadly accepted. ${ }^{7}$ As a result, much of the research inspired by Habermas has been firmly focussed on seventeenth and eighteenth-century news and opinionshaping publications, and on meeting places frequented by cultured citizens and the forms of politicization found there. One result is that sixteenth-century developments have been unjustly downplayed, to say nothing of such developments in the Middle Ages. ${ }^{8}$

\section{Points of Departure}

In this chapter we examine the process of the formation of public opinion in the early modern Low Countries with a special focus on the insufficiently examined role of literature in forming opinions and ways

\footnotetext{
${ }^{5}$ See, for instance, Van Dixhoorn, 'Chambers of Rhetoric'.

${ }^{6}$ Habermas, The Structural Transformation of the Public Sphere; translation of idem, Strukturwandel der Öffentlichkeit.

7 For a collection of criticisms see Calhoun, Habermas and the Public Sphere: see also Mah, 'Phantasies of the Public Sphere'. For a thorough German critique: Jäger, Öffentlichkeit und Parlamentarismus.

${ }^{8}$ For the existence of supra-local publics in the Middle Ages and early modern era see for example Scribner, 'Oral culture'; Wohlfeil, 'Reformatorische Öffentlichkeit'; Hadfield, Literature, Politics and National Identity; Faulstich, Medien und Öffentlichkeiten im Mittelalter 800-1400; idem, Medien zwischen Herrschaft und Revolte; Coldiron, 'Public Sphere / Contact Zone'.
} 
of thinking. We will attempt to show that-in contrast to assumptions made by Habermas and like-minded scholars-the early modern Low Countries did in fact have the potential to develop a public opinion, and that literary works were important in this regard.

In early modern society, literary texts were of great significance to both the shaping and the public expression of ideas. Among Dutch and Flemish literary historians it is now generally accepted that literary texts helped to form opinions. ${ }^{9}$ Unfortunately, in carrying out historical research into public opinion, sociocultural and political historians in the Netherlands and Flanders tend to ignore literary works as sources. ${ }^{10}$ It seems self-evident that the importance of literary texts can be properly understood only if the texts themselves, their authors, printers and publishers are studied as part of a broader process of opinion-formation, which often takes shape in a debate. ${ }^{11}$ We will demonstrate that it should be no less natural for historians to use responses to social, political, religious and other issues which appeared in a literary form as well as other sources. Such literary sources should be used, not primarily as a way of lending historical work an attractive style and artistic treatment but as documents that, in their own right, serve as an integral part of such investigations. The fact that literary works are a most important source has everything to do with the overwhelmingly oral (or: face-to-face) character of society in the early modern period. ${ }^{12}$

${ }^{9}$ Important advocates of this view include Herman Pleij and Marijke Spies. See also Van Stipriaan, Het volle leven. A methodological reconsideration of this point by Marijke Spies can be found in Joost van den Vondel, Twee zeevaartgedichten, ed. Spies, p. viii (our thanks to Anita Boele for this reference). Spies comments that the literary author 'confirms and sustains an idea, a tendency, an attitude, even when he is unaware of it. This often implies that he also takes a specific position with respect to social developments and therefore fulfils a function in opinion-forming in relation to such developments'.

${ }_{10}$ An exception is, for instance, Rodríguez Pérez, The Dutch Revolt through Spanish Eyes. Some historical studies that focus on the related topic of identity-formation also make use of literary works, including chronicles.

${ }^{11} \mathrm{An}$ exception in the older literature is Van Gelder's 'Satiren der zestiendeeeuwsche kleine burgerij'. A recent example of an early modernist who pays particular attention to the social role of literary texts is Frijhoff, Wegen van Evert Willemsz.

${ }_{12}$ Much relevant work has been done on early modern England-for instance in the volumes edited by Sharpe and Zwicker, Politics of Discourse and Reading, Society, and Politics in Early Modern England-but we aim to shed light on the situation in the Low Countries. 
Using literary texts as sources in research into processes of opinionformation requires a methodological and conceptual framework, in which starting points, research questions, research topics and methodologies are grounded in the relevant academic disciplines: the social sciences and historical and literary studies. In this article we aim to initiate the development of such a framework, in the belief that historical and literary-historical research into the significance of literary works in the process of opinion-formation is necessary in order to understand early modern society, and that such research increases our insight into the character of the literature of the period. We will also advocate allocating the Low Countries the place they deserve in the study of the history of publicity and the rise of public opinion as an independent force in social life. We are convinced that these regions of Europe, which were in many respects highly developed and offer a wealth of sources, ought to become important reference points in the debate.

We use a tentative definition of public opinion as a complex of beliefs about social, political, moral, religious and other public matters, one that can be found in larger or smaller segments of society and which originates and is expressed in a variety of ways. We focus on the entire process by which opinions are formed, in other words: on the formation of public opinion rather than on the individual opinions themselves. The ways in which views are shaped and expressed, whether publicly or not, are of course fundamental to this process. In early modern society those texts that we now call 'literature' were crucial to the shaping and dissemination of opinions. We will examine problems surrounding the concepts of literature and public opinion and attempt to come to a more precise working definition of both. Finally, we will delineate the starting points with which literary texts can be used to investigate the formation and functioning of public opinion in the early modern Low Countries.

\section{A PRECISE DEFINITION OF THE CONCEPT OF LITERATURE}

Defining what is meant by literature is problematic for a period in which the concept as we know it did not exist. In this article we approach issues as pragmatically as possible. We do not attempt to give an ontological definition of a universal category called literature; rather we take as our point of departure the forms and procedures that 
we now recognize as literary, even though we realize that this is no less problematic than attempting to offer a definition. ${ }^{13}$

Literature in our current sense is an anachronistic concept when applied to the early modern era, mainly because the distinction between literary and non-literary forms of expression and communication was far less clear-cut in that period, even non-existent. Many early modern authors operated in the shadow of classical authors, and in Antiquity, in the Middle Ages, and in the Renaissance period practically all written texts came under the heading of litterae ('written letters') from which our concept of 'literature' is derived. Furthermore, the concept of literature comprised not just written works but forms of oral literature such as poems and songs. In the Respublica litteraria (the international, indeed supranational Republic of Letters of the early modern period), which operated in Latin, people spoke of bonae litterae ('belles lettres'), meaning classical and patristic literature in a broad and comprehensive sense and the intellectual world that was bound up with it. This broad field of bonae litterae allowed people access to their classical heritage and the civilization of Antiquity. The term therefore came to stand for a particular cultural ideal and for learning and education in general, including a feeling for style and good taste, knowledge of history and mythology, expertise in the fields of language and letters, and a familiarity with philosophical and other intellectual movements. The Latin schools, which taught boys who were sent to them by ambitious parents, were based on this civilizing ideal plus the Latin language. Through them, as well as for example through organizations devoted to some or all seven of the liberal arts like the chambers of rhetoric, the same ideal permeated the non-Latin and non-literary worlds. ${ }^{14}$

${ }^{13}$ It has nevertheless been tried. See for example Abrams and Harpham, A Glossary of Literary Terms, pp. 152-53 under 'Literature': 'designates fictional and imaginative writings - poetry, prose fiction, and drama. In an expanded use, it designates also any other writings [...] that are especially distinguished in form, expression, and emotional power'. Korsten, Lessen in literatuur, p. 8 takes as his starting point the question 'What do people in specific sociocultural circumstances do with literature and what does literature do with them?' This evades the question of what literature 'is', or what (for example) the specific function of literature is in relation to other forms of text. See also Van Heusden, 'Omhelsd door de retorica'.

${ }_{14}$ These form one element of the studia humanitatis. See for example Grafton and Jardine, From Humanism to the Humanities, pp. 122-57 and 138-49; Kohl, 'Humanism and Education'. Classicists still employ a comparably broad definition of literature, encompassing poetry, scholarly texts in verse and in prose, history writing and 
In the early modern era writers based their approach to writing on the rules of rhetoric, or the art of speaking well. By implementing these rules, authors of literary texts attempted to formulate their thoughts eloquently. They paid heed to the rules governing invention (inventio), arrangement (dispositio) and style (elocutio) with their requirements of linguistic purity, clarity, ornamentation and aptness. ${ }^{15}$ Authors of texts we would now describe as non-literary, such as pamphlets, made use of the same rhetorical methods. ${ }^{16}$ Rhetoric aimed at convincing people, at changing their minds, so it had a persuasive function. ${ }^{17}$ In an early modern face-to-face society, in which written and printed books were still scarce, these were the means of creating convincing arguments. ${ }^{18}$ The result was a close connection between a predominantly oral and performative culture and the use of literary forms, such as the division into stanzas, repetition, rhythm, metre, melody, rhyme and hyperbole, as well as textual forms such as disputes and conversations, and allegorical representations of arguments.

In light of this, the definition of a work as 'literary' is mainly a matter of forms of literary encoding. Placards and minutes of meetings do not qualify as literature, but when the Haarlem rhetorician Louris Janszoon, in his play Het Cooren (The Grain), quotes an anti-monopoly placard almost word for word, he thereby moves the placard into the literary category. ${ }^{19}$ The reverse was also possible. In 1404-1405, when Jan Mattijssen, the city secretary of Den Briel, set down the common law in a hefty work, he punctuated his juridical text with a variety of short, anecdotal stories taken from the Bible, classical Antiquity, and contemporary history, intended as a means of illustrating the regulations. ${ }^{20}$ There is a reciprocal intertwining here between literary and

philosophical works. For the role of the chambers of rhetoric in the shaping of the cultural ideal of the liberal arts in the vernacular see Van Dixhoorn, Lustige geesten, pp. 214-54.

${ }^{15}$ For example Leeman and Braet, Klassieke retorica, pp. 98-117.

${ }^{16}$ See for example Vrieler, Het poëtisch accent. In the section 'Literatuur in pamfletten: de stand van onderzoek' (pp. 18-20) he completely passes over the question of what literature is. He focuses on poetry (which he defines as 'texts that rhyme').

${ }^{17}$ Leeman and Braet, Klassieke retorica, pp. 54-55.

${ }^{18}$ See Meijer Drees, 'Pamfletten: Een inleiding', pp. 11-18 on influencing readers. She too looks at literary aspects of the pamphlet but rightly decides not to define the pamphlet as distinct from literature.

${ }_{19}$ See Hummelen and Dibbets (eds.), Het Cooren (1565) van Lauris Jansz.

20 Taken from Pleij, Het gevleugelde woord, p. 22. 
explicitly non-literary forms, as was very common until at least the seventeenth century. ${ }^{21}$

The effect of texts that to us are clearly literary was comparable to that of pamphlets, for example, which arrived on the scene in the Low Countries after $1566 .{ }^{22}$ Although they are rightly seen as utilitarian or occasional works, their authors often made use of literary methods and forms. ${ }^{23}$ They sometimes did so quite extensively, even incorporating whole tragedies. Joachim Oudaen's Haegsche broeder-moord, of dolle blydschap (Fratricide in The Hague, or Mad Merriment, 1712), for example, can be regarded as a pamphlet. ${ }^{24}$ The stage play Auriacus, sive Libertas defensa (Orange, or the Defence of Liberty, 1599) by Caspar Ens was in many instances bound together with the essay in pamphlet form De iure belli Belgici adversus Philippum regem Hispaniarum (The Laws of War of the Dutch Against Philip, King of Spain), probably because the printer spotted a commercial opportunity. In so doing, to some extent he turned the play into a pamphlet, and it may have been read as such by contemporaries. Both the stage play and the essay convey arguments aimed at justifying the war against Philip II of Spain and, after he died in 1598, against Philip III. ${ }^{25}$

The concept of genre denotes a form of literary encoding that ostensibly differentiates literature quite clearly from other forms of communication. ${ }^{26}$ Early modern authors presented their literary products

21 'Poems', for example, appear in several of Verhoeven's newsletters: Simoni, 'Poems, Pictures and the Press'.

${ }^{22}$ For the breakthrough of the pamphlet in the Netherlands, see Harline, Pamphlets, Printing and Political Culture in the Early Dutch Republic.

${ }^{23}$ Vrieler, Het poëtisch accent; Clazina Dingemanse, Rap van tong, scherp van pen; De Kruif, Meijer Drees, and Salman, Het lange leven van het pamflet. See also Maczkiewitz, Der niederländsche Aufstand gegen Spanien (1568-1609), pp. 196-98 on the numbers of printed works that appeared in the Low Countries.

${ }^{24}$ See Joachim Oudaen, Haegsche Broeder-Moord, of Dolle Blydschap. Treurspel, p. 45. Compare also Duits, Van Bartholomeusnacht tot Bataafse opstand, p. 22.

25 Ens, Princeps Auriacus, sive Libertas defensa (1599), ed. by Bloemendal and Steenbeek. De iure belli Belgici adversus Philippum regem Hispaniarum (...) Seorsum accessit Princeps Auraicus sive Libertas Defensa. De iure belli Belgici, was published in Delft by Bruyn Schinckel, while Princeps Auriacus was published in The Hague by Albrecht Heyndricksz. Apparently Schinckel saw in the stage play a recommendation for the pamphlet. By 'pamphlet form', we mean a non-pretentious form of printed matter primarily focused on current issues, but it is clear that the concept of a pamphlet is no easier to define than the concept of literature. See for example Marijke Meijer Drees, 'Pamfletten: Een inleiding' and especially Verkruijsse, " "Gedruckt in seghwaer, op de pars der lijdtsaemheyt”. Boekwetenschap en pamfletliteratuur', esp. pp. 32-33.

26 See also, on theatre, Bloemendal, 'Receptions and Impact'. 
as morality plays, rhetorical farces, tragedies, comedies, tragicomedies or farces, or as epics, ballades or didactic poems, and in so doing they made conscious use of genre labels. According to modern concepts of genre, such texts, like songs and verses, fall under the heading of literature, but the example of the pamphlet demonstrates that no clear boundaries can be drawn around this criterion to distinguish such a text from other kinds of text. And what about dialogues, which in the form of the Colloquia by Erasmus undoubtedly belong to literature but are, as mere schuitepraatjes (gossip) and other genres that mimic everyday chitchat, always placed in the same category as 'trivia' and pamphlets? ${ }^{27}$ Still, in many texts with little in the way of literary allure, the literary form and encoding are clearly present. So it would be right to speak of a continuum from high-brow literary to low-brow literary categories and forms, in which high-brow stands for a clear ambition, a considerable level of knowledge, a high degree of intertextuality, and a sophisticated mastery of literary forms, while low-brow indicates the opposite.

In early modern times, works that used literary forms were present everywhere in daily life: at work, during protests, in times of political and social unrest, at festivals, in the tavern and in company, in church and in Bible groups, and they ranged from very informal to very formal, from low-brow to high-brow, from traditional to contemporary, from entertaining through moralizing, didactic and pedagogic to formative of opinion. As Hooft pointed out, literature was written and read but above all it was performed and spoken, and therefore watched and listened to. The ubiquity of communication across all layers of society primarily by means of performative literature meant that various literary interventions in social life were an ever-present channel through which erotic songs or drinking songs could circulate just as easily as political songs.

Given the questions we have asked ourselves, it seems best to set about the task pragmatically and define as literary texts all works in a form which we now categorize as literary (letters, poems, dialogues, stage plays, songs, etc.). Since we are concerned here with public opinion, our study will be limited to texts which were published, or written with the intention of being published, for a general public, and which aimed at informing, persuading or convincing that public. Moreover,

\footnotetext{
${ }^{27}$ For pamphlet dialogues like these see Dingemanse, Rap van tong, scherp van pen.
} 
they may have been circulated in both verbal and written form, as manuscripts or in print, circulated within formal or informal circles. ${ }^{28}$

Given the great variety of what we regard as recognizably literary ways in which authors expounded their opinions, some complicated and elaborate, some less complicated, it is pertinent to ask exactly why they opted for a particular form. The frequency and complexity of literary expressions used varied according to occasion and group. The type and sophistication of literary encoding were closely related to the sociocultural composition and geographical range of the audience, on the basis of which the author made a decision about the kinds of arguments he or she could make..$^{29}$ Beyond that, an author might choose a specific form for mnemotechnical reasons, which would determine the impact of the text on the public in time (memory) and space (transfer). The fact that texts and formulations were given a literary form was one reason why they remained relatively unchanged when they were disseminated among larger groups, in handwriting, in print, but above all by recital. A writer might continue to give his or her work a more formal and intertextual character because he or she aspired to a more general articulacy that rose above contemporary disputes. Other literary characteristics too, such as rhyme, repetition and rhythm, could

${ }^{28}$ The concept of literature has been the subject of much debate. See for example Brillenburg Wurth and Rigney, Het leven van teksten, esp. pp. 46-47: 'we take the core of literality to lie in the fact that some texts have a value of their own that is unrelated to their single, practical deployment'. Abrams and Harpham, A Glossary of Literary Terms under 'Literature': 'designates fictional and imaginative writingspoetry, prose fiction, and drama. In an expanded use, it designates also any other writings (including philosophy, history, and even scientific works addressed to a general audience) [italics JB and $\mathrm{AvD}$ ] that are especially distinguished in form, expression, and emotional power'). Vrieler, Het poëtisch accent, pp. 18-20 gives the current position of research but sidesteps the problem somewhat. De Kruif, Meijer Drees and Salman, in Het lange leven van het pamflet, p. 11, say of the pamphlet in terms of content that it has 'a close relationship to early modern texts recognized as literary'. Hadfield, Literature, Politics and National Identity, takes a very broad conception of literature as its starting point.

${ }_{29}$ Pleij, Het gevleugelde woord; in addition, for historical research into the communicative role of songs see for example also: Fumerton, 'Not Home'; Darnton, 'An Early Information Society'; Freist, Governed by Opinion, pp. 125-76. There is no in-depth study into the communicative role of the song and other literary forms in the Low Countries, although in Het volle leven, passim, Van Stipriaan does offer a wonderful synthesis. For the role of the song in youth culture see also Grijp, 'Het Nederlandse lied in de Gouden Eeuw' and idem, Het Nederlandse lied in de Gouden Eeuw, pp. 29-30. 
lend a message a charismatic or prophetic character, and so be used to evoke a degree of authority. ${ }^{30}$

Many texts which were given a literary form were deployed to reflect upon, announce, defend, confirm or contest specific ideas, opinions, projects, forms of behaviour or situations. The use of literary forms had everything to do with the peculiarities of early modern society, which, no matter how far the written word had penetrated public life, was in many senses vitally dependent on oral and performative means of communication. ${ }^{31}$ In this context, the choice of literary forms affected the degree and breadth of impact that the creator of a text could achieve.

\section{The Habermas Model and Various Forms of 'PUblic SPHere'}

As we have seen, Habermas claims that in the late seventeenth and especially the eighteenth century a 'bourgeois public sphere' developed in which enlightened minds could freely express their opinions about matters of general interest. By doing so these enlightened spirits institutionalized social criticism; the consensus that arose from the discussions they had with each other developed into the institution of public opinion. ${ }^{32}$

Habermas regards the opinion-shaping press as an essential factor in the development of the supra-local communities within which a population needs to communicate if it is to form its own public opinion. Public opinion in this sense emerged not only from the press, but also from discussions in eighteenth-century salons, coffee houses and concert halls, and in clubs and societies. There, Habermas says, a cultured public of critical and rational individuals began to focus on the previously forbidden domain of the state and its policies. The critical nature of this new public meant it was no longer possible for the state to ignore the consensus that flowed from such discussions. Criticism

\footnotetext{
${ }^{30}$ For older literary texts, see for example Kay, 'Grafting the Knowledge Community'.

${ }^{31}$ Performative media include rituals, but also prose texts read aloud, poems recited, songs sung and theatrical performances, always closely bound up with social life.

${ }^{32}$ Habermas, The Structural Transformation. A useful summary can be found in Goode, Jürgen Habermas. Democracy and the Public Sphere, especially pp. 3-12.
} 
of art and literature by cultured individuals ultimately laid the basis for the rise of public opinion as a political authority. ${ }^{33}$

One problem with this is that even in the late Middle Ages and the early modern era, literary texts, and indeed paintings and music, were not the products of an autonomous artistic sphere whose purpose was enlightened amusement; rather they were part of a multimedia system, and most were extremely political, religious, moral or social in content. Habermas does not in fact deny that this was the case, but he assumes that the art of the pre-Enlightenment was always bound up with efforts by the authorities to represent their own interests and power. He argues that late medieval and early modern Europe had a 'representative public sphere' that did not bear even a remote resemblance to a supra-local public of involved, informed, independent and rationally-minded individuals that supposedly was created in Enlightenment Europe. ${ }^{34}$

To Habermas, broad participation in widespread literary culture was very much a matter of the printed word in newspapers and books, which were discussed in local communities. This stance has occasionally been contested. Without any reference to Habermas, Robert Scribner had already pointed to the importance of the oral transmission of ideas for the rise of the Evangelicals as a mass movement in the early German Reformation. He showed that ideas were disseminated in print and were then distributed widely through oral, performative, handwritten and visual media. This interaction between many different modes of communication made it possible for local communities to become part of a supra-local movement, and for the ideas of the Reformation to be lent form through individual acts by ordinary people at a local level. ${ }^{35}$

${ }^{33}$ Habermas, The Structural Transformation. For a summary of this part of the theory in relation to eighteenth-century Berlin, for example, see Schulte-Sasse, 'Einleitung'.

${ }_{34}$ Boone, "In den beginne was het woord" points to Habermas's theory and asserts (although in passing in a footnote) that Habermas was wrong to dismiss the appropriateness of the concept of public space for the medieval and early modern periods. Boone correctly claims that in this sense Habermas clearly reflects the academic knowledge of the time in which he conceived his work (Habermas based his dismissal primarily on Huizinga's classic Herfsttij der Middeleeuwen, published in English as The Autumn of the Middle Ages).

${ }^{35}$ Scribner, 'Oral Culture'. Scribner makes extensive use of the insights of social science into social movements, but not of theories about the public sphere and public opinion. 
In 1984 the social historian Rainer Wohlfeil entered the debate about the extent to which the German Reformation can be seen as an early form of the bourgeois public sphere, as defined by Habermas's criteria. Picking up on Scribner's findings, Wohlfeil argued that this particular supra-local movement in a largely oral and face-to-face society met the criteria of general accessibility and political relevance that would qualify it as a social movement and its participants as a public. It seemed to him, however, that this in itself was not sufficient to allow us to speak of a bourgeois public sphere. According to Wohlfeil, supporters and opponents of the Reformation mutually excluded each other. Rather than striving for a free, open, and rational debate, people wanted to convince their opponents of a revealed truth. ${ }^{36}$

The German Reformation was not the only period in which, for a limited time, a public debate blossomed, with large groups of people participating. Thus Briggs and Burke argue that we should distinguish between temporary (or cyclical) and permanent (or structural) public spheres. Among those that were temporary they include the initial phase of the German Reformation, the French religious wars of 1560 onwards, the Dutch Revolt of 1566 and subsequent years and the English Civil War of the 1640s, all of which occasioned pamphlet-explosions of their own. In their view it was only after the seventeenth century that the public sphere became permanent with the rise of newspapers and periodicals, which unlike incident-related pamphlets or oral and performative media appeared with reliable regularity. Despite their attention to the world of oral, theatrical, and visual communication, then, these social historians also see the printing press as an important motor in the development of a permanent public sphere. ${ }^{37}$

In their limited revisionism, Wohlfeil, Briggs and Burke judged that the modern phenomenon of public opinion, which according to Habermas can only exist because of a structured opinion-shaping press, had a longer lead-in time than he assumed for the period characterized by what he calls a representative public sphere. An increasing amount of work on forms of communication in various European

\footnotetext{
${ }^{36}$ Wohlfeil, 'Reformatorische Öffentlichkeit'. The term, here translated as 'Protestant public sphere', was invented by the Marxist historian Jürgen Schutte. In contrast to Habermas's bourgeois public sphere, the Protestant public sphere was closely bound up with temporary social movements like that of the German Reformation and, according to Wohlfeil, came to an end with the institutionalization of German Protestantism, when it became simply a denomination.

${ }^{37}$ Briggs and Burke, A Social History of the Media, especially pp. 102-04.
} 
regions has cast considerable doubt on the primacy of the printing press as a means of generating a supra-local public sphere. ${ }^{38}$ Inspired by this, we would claim that the early modern Low Countries had a permanent supra-local public sphere as a result of the interaction of handwritten and printed works with the oral, performative and visual media of a face-to-face society, and that in this interaction literary works had an important part to play. ${ }^{39}$

\section{FURTHER CRITICISM OF HABERMAS}

It is undoubtedly the case that with the rise of printing the regularity, speed, volume and reliability of news and the dissemination of information increased. Opportunities for critical debate in which arguments could be compared and verified, and very possibly also the rational quality of public opinion, grew as a result. Habermas goes further, however, by claiming that the rationality of individuals who debated together as equals, rather than the collective learning process, formed the basis of the new eighteenth and nineteenth-century bourgeois public sphere. We may well ask whether this individual rationality can be so straightforwardly ascertained, but Habermas lays himself open to criticism above all on the grounds that, taking his lead from the Enlightenment philosophers, he excludes other contributions to the social debate. Such contributions certainly did exist and can be shown to be relevant, if only because they make visible the issues that

${ }^{38}$ See the research into (for example) the political Reformation in Scribner, Popular Culture and Popular Movements in Reformation Germany; Duke, 'Dissident Propaganda and Political Organization'; Van Nierop, 'Popular Participation in Politics in the Dutch Republic'. Apart from work on the history of the Reformation, this is also clear from the study by Tilly into supra-regional revolts, although he does not look at the communication networks and collective opinion-forming that made such revolts possible. See for example Tilly, Contention and Democracy in Europe, 1650-2000.

${ }_{39}$ Elizabeth Eisenstein has pointed out that the rise of the art of book printing had a fundamental influence primarily on the world of scholars, who already had a book culture. It is often wrongly assumed that she did not take into account the fundamental role of oral culture in late medieval and early modern society. See Eisenstein, The Printing Press as an Agent of Change, vol. 1, pp. xi-xvi and 5-30 and especially 10. The relationship between the spoken, written and printed word outside the academic world is explored by, for example, Scribner, 'Oral Culture'; Fox, The Spoken Word and idem, Oral and Literate Culture in England 1500-1700; Pettegree, Reformation and the Culture of Persuasion. Like Eisenstein they emphasize that the spoken word was often written down or printed and the printed word was often read aloud. 
preoccupy a society. These may be religious convictions, norms, experiences, feelings or habits and customs, or they may be the grievances and vested interests of individuals and collectives. ${ }^{40}$

Historians hoping to find traces of the formation of public opinion should therefore not only focus their attention on literate and rational discourse between articulate individuals but look for other, less literate, rational and eloquent, indeed sometimes raucous forms of debate in which individuals and collectives were able to set themselves up as spokespeople and try to attract attention. The degree to which individuals and groups adhere to certain rules about the rational exchange of ideas is only one aspect of the public debate. ${ }^{41}$ Moreover, the requirement of rationality is a criterion that, no less than the appeal to authorities or cultural taboos, can be used as a weapon in an exchange of opinions to force anyone who is not a member of the dominant group to remain silent in public. ${ }^{42}$ It is, therefore, a rhetorical argument.

The idea that literary and artistic life in the late Middle Ages and the early modern era was closely bound up with government bodies has in any case been superseded. Social, religious and political movements in medieval and early modern Europe made use of relatively independent internal channels of communication to convey news, express criticism, mobilize and make visible oppositional forces, put pressure on the authorities and sometimes even to take political action. From this it is clear that a supra-local sphere of communication existed, which facilitated the circulation and digestion of news and ideas beyond the sphere controlled by the authorities. As we have seen, the live performance of music and rituals, and the public recital of textsranging from edicts and sermons to songs, poems and works for the

${ }^{40}$ Jäger, Öffentlichkeit und Parlamentarismus, pp. 70-71 criticizes above all the criterion of rationality and individual learning capacity, which overestimates the individual. Schulte-Sasse, 'Einleitung: kritisch-rationale und literarische Öffentlichkeit', p. 22, points out that not only Reason but moral and sensory experiences too are expressed in public (especially through literary texts). Moreover, Jäger points to nonliterary forms of protest such as marches, strikes and riots. Similar argumentation can be found in $\mathrm{Ku}$, 'Revisiting the Notion of "Public" in Habermas's Theory'.

${ }^{41}$ We understand the concept of a debate metaphorically here, given that we hardly ever come upon a direct debate alone, such as can take place between two or more persons.

${ }_{42}$ For this argument, see for example Fraser, 'Rethinking the Public Sphere', especially pp. $10-12$. 
stage-contributed to this supra-local sphere, alongside the material media of manuscripts and books, paintings and prints. ${ }^{43}$

Another problem with Habermas's model of the bourgeois public sphere is that it takes no account of the mechanisms of inclusion and exclusion that determine who is allowed to speak or to listen and who must remain silent in debates about matters of relevance to a given community, at the level of the state, a region, a town or even a neighbourhood. The public, which Habermas sees as made up of rational individuals, exchanging ideas on the basis of equality and developing a consensus according to who has the best argument, is itself no more than a subsection of society, namely male members of the higher bourgeoisie, who adhere to a specific norm governing the reciprocal exchange of views. It is impossible even for the bourgeois citizen himself to comply fully with that norm of rationality. Conversely, early modern societies included groups of people who strove for a form of public wisdom, such as humanists and other men of letters.

Habermas's model disguises the fact that in complex societies a battle is fought for ideological hegemony in the public domain, and the groups that make themselves heard the loudest and are the most visible to everybody else are the groups best able to put themselves forward as representatives of the public interest. To Habermas it does not matter whether such a group is the one most representative of the people as a whole, only whether it best serves the rational interest of the whole. The crucial question, however, is: how, and by which public, is this interest formulated? It is not a naturally existing fact: all kinds of economic, religious, cultural, moral, emotional and political motives contribute to the formulation of this interest. ${ }^{44}$

The notion of the public, a notion crucial to Habermas, presupposes interaction, participation and a degree of activity. ${ }^{45}$ It also assumes

\footnotetext{
${ }_{43}$ Briggs and Burke, A Social History, pp. 74-105; Pettegree, Reformation and the Culture of Persuasion; Marnef, Antwerpen in de tijd van de Reformatie, pp. 47-76.

${ }^{44}$ The general interest is always defined through mutual exchange. Again it is the dominant group that can use its ideas about the public interest to fend off other ideas from the opinion-forming and policymaking process by presenting them as reflecting the interests of specific groups. See also Fraser, 'Rethinking the Public Sphere', pp. 10-20 and for the Low Countries in the sixteenth century also Van Dixhoorn, "The Grain Issue of 1565-1566'.

${ }^{45}$ Sociologists and, following on from them, historians have strongly linked the concept of 'public', like the concept of 'masses', which by contrast assumes no interaction, participation or activity, to modern society. Rarely if ever is it used in an analysis of medieval or early modern society.
} 
the existence of a world in which specific institutions, persons and subjects are attended to, followed and featured in the news and in information supplied to others. According to Habermas the public consists of those who follow what is written in the press and exchange ideas about social issues. Since even in the Middle Ages and the early modern period people could become involved in an exchange of ideas about their society, by conversing with each other and through oral or performative and written literature, it is no longer tenable in an examination of the formation of public opinion to separate the early modern period fundamentally from modern times.

Moreover, Habermas uses an extremely strict definition of the public, which he presents as a single entity composed of individuals. In so doing he blocks our view of the various collectives that, using the means of communication available, can emerge within a society around themes, concerns and living conditions. Above all Habermas ignores the many forms of involvement in society as well as the many attempts to exert influence at a non-national level. ${ }^{46}$ At the same time he neglects the fact that in the early modern world too people operated as individuals and as such participated in informal networks and circles.

It seems, given this criticism, that it would be better to broaden the investigation and turn our thoughts to the identification, description, and analysis of the ways in which opinions are formed about specific social issues, and how they influence politics and society in various times and places, paying attention to all groups involved in the process and gaining greater insight as a result.

In this connection it might be useful to adopt Agnes Ku's proposal and define the burgher not in socioeconomic terms as a bourgeois individual, as Habermas does, but in the political-social sense of membership of a state and active participation in society, and therefore as a citizen. A shift from the notion of the bourgeois public sphere to that of the public sphere of the citizenry would point to concrete forms of political and social engagement by individuals and groups with different sociocultural backgrounds, interests, ideas and means of expression. ${ }^{47}$ Such an interpretation also produces a concept that

${ }^{46} \mathrm{Ku}$, 'Revisiting the Notion of "Public"'. Other examples include: Dunckelmann, Lokale Öffentlichkeit; Schulte-Sasse, 'Einleitung', p. 22; Splichal, 'Defining Public Opinion in History'.

${ }_{47} \mathrm{Ku}$, 'Revisiting the Notion of "Public"'. 
is less Eurocentric and more easily applicable to the study of social engagement in both historical and non-Western societies.

Habermas has created another analytical problem for those who study societies outside modern Europe and therefore also for historians. Critics have shown that he does not make a clear distinction between the public as a social reality (which he then goes on to identify too strongly with a single social group) and the symbolic public of public opinion that is regularly conjured up in political and social rhetoric whenever someone, or indeed a group, claims to speak on behalf of the whole population. Though he does not study concrete instances of social debate, Habermas believes that debates within a bourgeois public always lead to a real consensus, in the form of public opinion..$^{48}$

A presumed consensus under the heading of public opinion (or other concepts with the same import) cannot be a social reality, and is therefore a fiction. Public opinion as a unity or consensus is a symbolic construct, although it does have an actual impact on political rhetoric in that it helps to create moral authority for the state and for groups in the public sphere. In the battle waged to decide which people and ideas best represent that symbolic public (the battle, mentioned earlier, for hegemony in the public sphere), the real (always divided) public is naturally of great importance. The fiction even assumes the existence of an interested population that is capable of a discernible process of collective formation of opinion. ${ }^{49}$ Texts that take a literary form are extremely useful when it comes to imagining such a public. It is clear that in the kind of argumentative and didactic literary works that were produced in the early modern era, a public in this sense was indeed frequently conjured up. ${ }^{50}$

${ }^{48}$ Habermas, Strukturwandel der Öffentlichkeit. He does actually recognize a fictive element in the formation of public opinion, p. 69: 'Die entfaltete bürgerliche Öffentlichkeit beruht auf der fiktiven Identität der zum Publikum versammelten Privatleuten in ihren beiden Rollen als Eigentümer und als Menschen schlechthin', but he does not analyse that fictive element any further. A useful summary of his ideas about the development of public opinion in the eighteenth century can be found in Goode, Jürgen Habermas: Democracy and the Public Sphere.

${ }^{49}$ On the fictive element see Ku, 'Revisiting the Notion of "Public"'; Mah, 'Phantasies of the Public Sphere'; Splichal, 'Defining Public Opinion in History'; and Allport, 'Toward a Science of Public Opinion', especially pp. 51-54.

${ }^{50}$ See for example Schulte-Sasse, 'Einleitung', p. 22. For the role of literary techniques in the representation of the public see Baudin, 'The People in Seventeenth-Century 
Habermas's analytical blending together of the formation of the public as a social phenomenon, the formation of public opinion as a phenomenon of communication and interaction, and 'the public' and 'public opinion' as rhetorical elements within that process of communication points to a deeper problem. Habermas does in fact assume that the development of specific concepts like public opinion and the bourgeois public sphere have a direct relationship with socioeconomic and political developments. ${ }^{51}$ As we have demonstrated, Habermas has taken a rhetorical strategy used by a specific segment of the population, the eighteenth-century bourgeoisie, to be descriptive of the sociocultural reality that he then goes on to analyze. By recognizing the rhetorical function of concepts such as 'the public' and 'public opinion' and analyzing their effects on society, we can take an important step in the direction of a case-oriented analysis of the process by which public opinion is formed.

The PUbLIC SPHERE, PUBLIC OPINION AND COMMUNICATION THEORIES

In the rest of this article we wish to develop a number of starting points for the concrete study of texts and the formation of public opinion. We will use social science studies that make it possible for historians to think beyond Habermas. These starting points are also intended to underline the need to make the inclusion of literary texts a standard feature of studies that investigate how opinions about social matters have been shaped.

Habermas's concept of opinion, which has been hugely influential in historical studies and in political and social philosophy, bears a very close resemblance to the classical-elitist definition that emerged from the Enlightenment. It regards public opinion as a consensus reached through enlightened and rational discussion within well-informed circles and made visible in the quality press. ${ }^{52} \mathrm{~A}$ more modern interpretation of public opinion can be found in definitions used in studies of

French Tragedy'; and more recently Hadfield, Literature, Politics and National Identity; Freist, Governed by Opinion, pp. 239-306.

${ }^{51}$ Habermas, Strukturwandel der Öffentlichkeit, pp. 16-78.

${ }^{52}$ For the classical-elitist conception see among others: Lippmann, Public Opinion; Lazarsfeld, 'Public Opinion in the Classical Tradition'; and of course Habermas, Strukturwandel der Öffentlichkeit. 
modern democracy or in the social sciences. They equate public opinion with the sum of opinions within a population..$^{53}$ Criticism of both definitions (that the one is too limited and the other too static) has produced a third. This sees the concept of public opinion as designating a dynamic process of opinion-formation that involves politicians, the media and a wide variety of interest groups, a complex phenomenon that can be found in one form or another in all societies. ${ }^{54}$ This definition has gained ground since the 1990s in work on the dynamics of the formation of public opinion and is particularly relevant to historical research. ${ }^{55}$

In both the classical-elitist and the postmodern definition, the concept of public opinion is closely related to the concept of a public sphere: public opinion is an observable phenomenon, whether the emphasis lies on the consensus (the fiction) or on the process by which opinions are formed. At first sight this seems rather less true of the modern democratic definition, since it includes opinions that people keep to themselves; it sees public opinion as 'the sum of opinions held by all people'. In its explanation of the way in which human opinions are formed and altered, however, the concept of a public sphere also arises immediately, not just because of the importance traditionally assigned to the media but because of a recognition of the relevance of political parties and social movements, and a realization that family members, friends and acquaintances are of crucial importance in the formation of opinion. The notion of a public sphere is closely connected to the public (or publics) in the sense of an audience or readership. As an object of research, 'public opinion' therefore includes the entire process of the formation of opinion within a specific public, of which public opinion as a fiction is an important element.

We can say something is public when specific speakers, consciously or not, communicate openly with an audience, the scope of which they

${ }^{53}$ This conception is at the root of the entire modern industry of opinion polling. See for example Converse, Survey Research in the United States. For a strict version of this concept of opinion see also Brettschneider, Öffentliche Meinung und Politik. For the history of the concept see also: Peters, 'Historical Tensions in the Concept of Public Opinion'; Zaller, The Nature and Origins of Mass Opinion; Price, Public Opinion; and Noelle-Neumann, 'Public Opinion and Rationality'.

${ }^{54}$ An early example of this assertion can be found in Mead, 'Public Opinion Mechanisms Among Primitive Peoples'. See also Noelle-Neumann, Öffentlichte Meinung.

${ }_{55}$ Kaase and Pfetsch, 'Umfrageforschung und Demokratie', especially p. 158. Crespi, The Public Opinion Process, pp. 114-26; Fishkin, The Voice of the People; Herbst, 'On the Disappearance of Groups'; Herbst, Reading Public Opinion. 
cannot entirely determine for themselves. Societies in which relatively free and intensive communication takes place between individuals and groups have a public sphere in which speakers and audiences can confront each other with their ideas on a regular basis. Where speakers and audiences encounter one another, be it in a physical or a virtual meeting place, speakers can express their opinions on specific subjects directly or through various media. The larger the audience, the less certainty a speaker has as to the effects of what he or she says. ${ }^{56}$

The public sphere is often conceived as a system of real and virtual meeting places: networks, institutions, theatres, coffee houses and societies, alongside newspapers, periodicals and other media. ${ }^{57}$ This approach regards the way in which the public sphere comes into being as highly dependent on such structures. The greater the sociability within a society, the more channels of communication and instances of communication it will have. The intensity of social life has a bearing on the public impact of what people and the media say. The way in which players in the public sphere are organized influences the form and range of a message. Anyone researching the public sphere along these lines will concentrate on the structural and infrastructural preconditions of its existence. This is a route that many historians have taken, especially those studying the late seventeenth and eighteenth centuries. Alongside this system-oriented approach, an actor-oriented approach is also possible..$^{58}$

An actor-oriented approach shifts the attention to the interplay between actors, in other words to the speakers and their audience, and its effects. In the communication process that produces a public sphere-public in the sense that it is generally accessible and visiblethe speakers involved fulfil specific social roles. Individual players and collectives, such as governments, businesses, churches, associations, pressure groups and media organizations, may act as authorities, experts, representatives, shapers of opinion or intermediaries. Depending on the occasion, players can switch from being members of the audience to being speakers and vice versa. ${ }^{59}$

\footnotetext{
${ }^{56}$ Neidhardt, 'Öffentlichkeit, öffentliche Meinung, soziale Bewegungen', especially pp. 7-8, with a reference to Habermas.

${ }^{57}$ Habermas, Strukturwandel der Öffentlichkeit; see also for example Van Vree, De politiek van de openbaarheid.

${ }^{58}$ Raupp, 'Zwischen Akteur und System'.

${ }^{59}$ Ibidem.
} 
The public sphere can therefore be seen as the outcome of social interaction between speaker and audience, whether direct, indirect or created by the media. In a social system, even one as uncontrolled and fragmented as the public sphere, all kinds of processes of integration and exclusion exist. The difference in roles assigned to players in the public sphere is influenced in part by the specific forms of knowledge and social capital that people have at their disposal. Not every individual can fulfil every role equally well. Some will be more capable of actively seeking out their own opportunities and conditions for communication and capitalizing on them. Others are more passive or may even be excluded by the chosen means of communication, the Latin language for example, from any possibility of receiving a particular message. Many other obstacles stand in the path of people hoping to act as speakers in specific ways, especially when it comes to the more organized roles in today's media. ${ }^{60}$

Communication that leads to publicity can be either verbal or nonverbal. The strategy chosen by a speaker for reaching an audience depends on the intended effect, the opportunities within the existing infrastructure, and the assessment the speaker makes of the expectations and potentials of the audience. Speakers can strive for maximum publicity, or they can aim at a more limited audience through a specific target group. ${ }^{61}$ Both formally and informally organized networks and channels can contribute to the creation of a public sphere. Formal publicity originates in the social interaction between institutional players and individuals and loosely formed groups. Informal publicity originates in daily contact between two or more people. Such contact is still one of the most important sources of publicity, but clearly in early modern societies it was the pre-eminent source. ${ }^{62}$

Every message that is made public is compiled in a specific code and made up of verbal or non-verbal signals. The recipients of a public utterance have to be able to decipher that code if the message is to be effective. Successful communication therefore also demands a shared knowledge of the language, symbolism and frameworks of interpreta-

\footnotetext{
${ }^{60}$ Raupp, 'Zwischen Akteur und System'; Westerbarkey, 'Öffentlichkeit und NichtÖffentlichkeit’.

${ }^{61}$ In practice, the audience of a message can never be unlimited, no matter how hard a speaker or his or her intermediaries try to reach as far and wide as possible. Raupp, 'Zwischen Akteur und System', pp. 121-22; Westerbarkey, 'Öffentlichkeit und Nicht-Öffentlichkeit', pp. 152-54.

${ }_{62}$ For the informal public sphere see Evers, Informele openbaarmaking.
} 
tion used between speakers, intermediaries and audience. The content of the message depends on both the level of knowledge of the speaker and his or her estimation of the audience. After all, the accuracy of the latter determines the message's effectiveness. Depending on its level of knowledge, the audience will be able to perceive, absorb, digest or reject the message in a more or less active way. This is quite important to the speaker and any intermediaries whom he or she may use. It is too simplistic to say that a speaker selects an audience, since the audience decides which message or which medium to pay attention to and how. Speaker and audience are therefore mutually dependent, and clearly the most ambitious and most engaged among them will compete for the most advantageous positions in the public sphere. ${ }^{63}$

Publicity is as continuous or discontinuous as the communication process from which it results. It undoubtedly gains in continuity when durable social relationships develop, since the players who shape the public sphere through their interactions develop fixed and recognizable roles, patterns of behaviour, and mutual expectations. An intensive social life and an extensive infrastructure are important preconditions. The tighter the formation of networks around the players, the more durable the public sphere will become, as a result of the intensity of communication within it. ${ }^{64}$ Studies of actors in a public sphere will therefore always have to take account of the space the public infrastructure offers them. Insight into the process of information provision and the formation of opinions and judgements in broad groups within a society will therefore always be dependent on an analysis that combines a focus on the structure and infrastructure with a focus on the actors.

\section{Media, PUblic issues AND PUblic Debate}

When, in the endless stream of opinions and information in the media or in public exchange, or both, a single theme arises repeatedly, we can speak of a public issue, one that is generally known. A controversial

\footnotetext{
${ }^{63}$ Raupp, 'Zwischen Akteur und System', pp. 121-22; Westerbarkey, 'Öffentlichkeit und Nicht-Öffentlichkeit', pp. 152-54.

${ }^{64}$ For the early modern era see for example Wohlfeil, 'Reformatorische Öffentlichkeit' and Briggs and Burke, A Social History, pp. 102-04. On the importance of sociability see also (for example) Agulhon, Le cercle dans la France bourgeoise 1810-1848, pp. 7-14.
} 
public issue can lead to a broad exchange of views, in which case it will give rise to a public debate. It is possible to discern five phases in the development of public debates. In the first phase the problem is recognized by a group of people and crystallizes into a recognizable topic; those involved know what it is about and what their personal opinion is. In the second phase various possible solutions are explored and discussed. In the third phase groups crystallize, made up of advocates of specific solutions who then go in search of more support and try to create a broadly accepted consensus based on their own proposals. In the next phase the solution with the largest number of supporters or the greatest influence is carried through and put into practice, after which comes the final phase, the evaluation of the chosen solution and its effects. ${ }^{65}$ In addition, it may very well be that lasting public discord arises. ${ }^{66}$

In this model the formation of public opinion is a route by which people in a society can present social problems to each other, put them into words, and then look for solutions. The questions are: how did this happen in early modern society, and what part was played by literary works in the development, formulation, publication and recording of problems, arguments, proposals and social projects?

The role of the media merits closer examination. Research in communication studies in which the relationship between the public and the media is approached by means of three separate theories attributes to the latter a high degree of social influence. In our society the media are a constant presence and they exert great pressure on the public. This is not to say, however, that their influence is direct. People appear able to put up a great deal of resistance to direct influence by the media, mainly because they fit the information into their existing world of ideas and experiences and absorb news selectively, commonly through interaction with those close to them (the usersand-gratifications theory). Media influence is also dependent on other factors, such as public faith in the media, freedom of expression, the general level of education, prior knowledge, existing convictions, previous experiences, the intensity and quantity of media consumption and of social contacts, and the position of the media in the informal public sphere. But even people who have little contact with the discus-

65 Price, Public Opinion, p. 31; compare Noelle-Neumann, Die Schweigespirale, pp. 219-20 (published in English as The Spirals of Silence).

${ }_{66}$ Neidhardt, 'Öffentlichkeit, öffentliche Meinung, soziale Bewegungen', pp. 7-8. 
sion of issues in the formal media and have strong convictions of their own will notice the influence of the media, unless they are completely isolated socially. ${ }^{67}$

The media select the news and information that will be disseminated most widely, they decide which persons, bodies and groups, and which arguments, will most often be heard and seen, and within which frameworks of interpretation this will take place. So they have a huge influence on the social agenda. Conversely, people, groups and bodies within a society have an influence on the media agenda (the agendasetting theory). The less freedom the formal media have, the greater the role of informal circles, which fulfil the same agenda-setting function. The media expand the reservoir of knowledge, opinions and arguments, and they strengthen interaction within the involved and active public. They have an impact even if only a small group becomes aware of the message, since there is a fair chance that this small audience will in turn share its knowledge and insights with others. In societies where the media cannot disseminate messages to a broad audience, those who do receive media input seem to play a particularly important role in funnelling knowledge and insights onwards (the two-step-flow theory).$^{68} \mathrm{~A}$ similar notion has been formulated for the early modern period in relation to intermediaries between the culture of the literate elite and popular oral culture. ${ }^{69}$ These intermediaries are sometimes called opinion leaders. ${ }^{70} \mathrm{~A}$ different group of opinion leaders is active within the organized media. ${ }^{71}$

\footnotetext{
${ }^{67}$ Stappers, Reijnders, Möller, De werking van massamedia; Schenk and Rössler, 'Das unterschätzte Publikum'; Zaller, The Nature and Origins of Mass Opinion; Lenart, Shaping Political Attitudes, pp. 98-108; Glynn, Ostman, and McDonald, 'Opinions, Perception, and Social Reality'; Page and Shapiro, The Rational Public; NoelleNeumann, Die Schweigespirale.

${ }^{68}$ Stappers, Reijnders, and Möller, De werking van massamedia, pp. 189-91; for the two-step-flow theory of two pioneers of modern opinion research see Katz and Lazarsfeld, Personal Influence.

${ }^{69}$ Vovelle, 'Culturele tussenpersonen'; Frijhoff, Wegen van Evert Willemsz.

${ }^{70}$ Price, Public Opinion, pp. 200-01 refers to the well-known study by Moscovici, which has shown that the 'conversion' of people who take up central positions in interpersonal networks was a key step in the process of diffusing agricultural and technological innovations. Comparable findings are in Katz and Lazarsfeld, Personal Influence, where the role of opinion leaders (those who are first and most thoroughly exposed to influences from the mass media) are central to social groups. For a historical application of their theory see Scribner, 'Oral Culture'. On the role of people with strong convictions see Billig, Ideology and Opinions, pp. 190-92. See also Maczkiewitz, Die niederländische Aufstand, pp. 194-96.

${ }^{71}$ Noelle-Neumann, Die Schweigespirale, pp. 200-05, 222-40; Converse, 'The Nature of Belief Systems in Mass Publics', on the role of political parties and an elite
} 
All three of these models assume interaction between media and public, whether the public fits messages from the media into its existing world of ideas and experiences, influences the media agenda, or passes on knowledge and insight to others. The question is: how, in the light of this, should we assess the importance of literary texts whose function in the early modern era resembled that of the media today?

\section{THE EARLY MODERN PUBLIC SPHERE}

As we have seen, the early modern public sphere was characterized primarily by informal networks in which news and opinions were formed and disseminated. ${ }^{72}$ Institutional players in the public domain were the various governmental bodies, the churches and other religious organizations, educational institutes, literary societies and, of course, printers. In a certain sense public festivals, ceremonies and competitions, which local communities organized regularly in the late medieval and early modern periods, also formed an institutionalized public sphere that presented plenty of opportunities for theatrical performances, the reciting of verses and the singing of songs. The social character of these events ensured at the same time that they amounted to meeting points in informal public spheres. ${ }^{73}$

In the late Middle Ages and the early modern period at least, the public provision of news and the formation of public opinion were collective projects to which many individuals contributed and which operated through an informal web of individual conversations, private correspondence, leaks of secret information, and perpetual guesswork and deductions based on available facts, personal experiences and frameworks of interpretation. The more formal media landscape was organized very differently to the way it is today. Until the early seventeenth century there were no periodicals, newspapers or magazines producing news in a structured manner. Newsgathering was the work

public as opinion leaders. The literature on leadership of opinion in the formal media is, as far as we can see, limited. For the early modern Low Countries see Van Dixhoorn, Lustige geesten, pp. 255-423; and idem, 'Soorten rederijkers'.

72 One famous story is that of Hugo Grotius's escape from Loevestein, a tale that was known throughout the country within a few days. See Nellen, Hugo de Groot, p. 260.

${ }^{73}$ Van Dixhoorn, Lustige geesten, pp. 301-43; idem, 'Liefhebbers van de redekunst'; Van Bruaene, "A wonderful triumfe, for the wynnyng of a pryse"'. 
of the public itself and the publication of news in print was done on an incidental basis. To the extent that news and opinion were disseminated by means of the printing press (in the form of pamphlets and newssheets), authors, printers, publishers and the book trade formed the editorial system that chose which items to publicize and expressed opinions on them.

Merchants, innkeepers, diplomats and government officials in particular were continually looking for news as part of their social function. Until well into the seventeenth century, however, there were too few people seeking out domestic news, information and opinions to warrant publishing them regularly. Newsgathering was mainly in the hands of interested parties and of inquisitive and well-informed members of the public who had close ties with each other and access to the right sources. Because they determined what kind of information they deemed important to collect, they had a crucial editorial function in the mainly oral process of forming public opinion and deciding which events were newsworthy. ${ }^{74}$ The other media were closely involved with this oral world. The formation of opinion and the provision of news and information could take place through the recital of poems, the singing of songs and performances on stage, as well as through the organizing of tableaux vivants and displays of images at official ceremonies. News, information and opinions were also distributed in the form of written and printed texts, paintings and prints, stained glass windows, clothing and rituals. The educated and the illiterate, holders of power and private persons all made use of these media to disseminate their opinions. Many had access to these opinions as long as they attended certain events, or could appreciate written works either because they were able to read or because people around them were willing to read aloud. But be it through the stage or the written word, ideas could be spread further because after the performance or the reading they were discussed. ${ }^{75}$ It seems that at times of growing public debate the

\footnotetext{
${ }^{74}$ For early modern systems of news, oral or otherwise: Cust, 'News and Politics in Early Seventeenth-Century England'; Fox, 'Rumour, News and Popular Political Opinion'. For the Low Countries see Van Nierop, "'And Ye Shall Hear of Wars and Rumours of Wars"'.

${ }^{75}$ Most of the assimilation may in fact have taken place at this stage. See Eversmann, 'The Experience of the Theatrical Event'.
} 
number of opinion leaders increased, the media expanded, new media spread more quickly, and old media became easier to revive. ${ }^{76}$

In the Low Countries from the mid fifteenth century onwards, supralocal literary networks developed, made up of learned individuals and 'amateur scholars' within the local chambers of rhetoric. There all sorts of matters of public opinion were placed on the agenda and discussed, so that the chambers fulfilled an editorial function, as it were, within a communication system that bound together the oral and visual world with that of the written and printed word. ${ }^{77}$

An important role in the development of public controversy is reserved for those who do not keep an opinion to themselves, since they believe it to be of concern to others as well. They therefore place it on the public agenda, thus taking the initiative in describing a public concern. As we have seen, a public issue arises only when others recognize the problem and make it their own, at which point a discussion can begin as to the description of the problem and its solution. Such processes of collective formation of opinion grow more complex as a society becomes more complicated, and with it the problems about which people have to form judgements. ${ }^{78}$ In order to recognize collective (public, generally accessible and known) problems and to be able to solve them, people need access to the relevant channels of knowledge and information. This brings us back to the oral circle that was crucial to early modern society. As news is passed by word of mouth it is continually 'edited' as information is removed, supplemented, revised and reformulated, so that the message is composed of the knowledge and opinions, both implicit and explicit, of all those who give shape to it. ${ }^{79}$

In contrast to meetings of small groups, in a society that transcends the local level it is hard to determine how many people hold a particular opinion. If the matters involved are controversial it soon becomes

\footnotetext{
${ }^{76}$ Van Dixhoorn, Lustige geesten, pp. 89-91; Briggs and Burke, A Social History, pp. 102-04.

77 Van Dixhoorn, Lustige geesten, pp. 257-63. For the mechanics of news networks, domestic or international, of learned people in the early modern Republic see also (for example) Stegemann, Patronage and Services in the Republic of Letters, p. 435.

${ }^{78}$ Habermas correctly pointed this out. For a brief overview of the different phases in the public debate see also De Boer and 't Hart, Publieke opinie, pp. 43-45; NoelleNeumann, Die Schweigespirale; and Neidhardt, 'Öffentlichkeit, öffentliche Meinung, soziale Bewegungen'.

${ }^{79}$ See also Darnton, 'An Early Information Society'.
} 
even more difficult. Assessing which standpoints are supported by a majority or by a minority is crucial to the dynamics of the process of opinion-formation. In early modern societies, however, it was enormously difficult to tell how widely represented a given view was, and for historians it is no easier to determine this. People and groups undoubtedly observe and judge each other all the time, and in addition they look at how institutions deal with issues, forming judgements about them on that basis. This observation and judgement of others ultimately forms the core of the process that creates public opinion. ${ }^{80}$ And it is in this process that the 'fiction' of public opinion, and the fiction of a public that would agree with an opinion, arise. Through what people hear others say, through what they see and read (and tell others about) they form an impression of what 'the common folk', 'people', 'one', 'everybody' or 'the community' thinks. ${ }^{81}$

Literary texts were of great significance in the creation of the early modern fictive public. Whether a text reflects a broadly held opinion or the opinion of one individual, as soon as that opinion is presented as a broadly held belief or consensus, that very fiction in itself helps to form opinion. To take a simple example, when Leiden rhetorician Jacob Duym stood up in favour of continuing the war against Spain in his Moordadich Stuck van Balthasar Gerards (Murderous Act of Balthasar Gerards, 1608), by presenting the attack on William I, the 'father of the fatherland', as a foul murder committed at the instigation of the Spaniards, he made it seem as if the general attitude to Spain was extremely negative. ${ }^{82}$ In the play, the trio of Spanish Council, Bloodlust and Inquisition incite Balthasar Gerards to the murder of Orange. The identification of Spain with tyranny was, of course, meant to fuel dislike of Spain. Whatever influence this play may have had on the

${ }^{80}$ A fundamental analysis of the role of observation in the process of opinionformation can be found in Noelle-Neumann, Die Schweigespirale. See also: Darnton, 'An Early Information Society'; Farge, Subversive Words; Fox, 'Rumour, News and Popular Political Opinion'; and Van Nierop, '“And Ye Shall Hear of Wars and Rumours of Wars"'.

${ }^{81}$ Interesting examples of the process of weighing up the opinion of 'the community', etc., in the early modern Low Countries can be found in chronicles. See for example Van Haecht, De kroniek van Godevaert van Haecht over de troebelen van 1565 tot 1574 te Antwerpen en elders, ed. Van Roosbroeck; Chronycke van Antwerpen sedert het jaer 1500 tot 1575; Van Vaernewijck, Van die beroerlicke tijden in die Nederlanden en voornamelijk in Ghendt, 1566-1568, ed. Vander Haeghen.

${ }^{82}$ See Duym, Het Moordadich Stvck van Balthasar Gerards, ed. Serrarens and Wijngaards. 
formation of opinion about the peace and on the actual negotiations, the fact is that in the years before 1609 the aim was not lasting peace but a temporary truce. The play was one of the voices that created the public climate in which the negotiators had to operate. How and to what extent they were truly influenced by it is another matter. ${ }^{83}$

In 1619 Job A. van de Wael, factor at the Flemish chamber of rhetoric 'De Akerenboom', wrote a play called Schiedams Rood Roosjens Spel, van David ende Goliath (Schiedam Play for Red Rose, of David and Goliath). It was his entry for a competition held by the Schiedam chamber 'De Roode Roosen'. ${ }^{84}$ At a time when the disputes between Maurits and Oldenbarnevelt, between Remonstrants and CounterRemonstrants, and between the parties favouring war and peace were approaching a conclusion, Van de Wael had written a play in which Maurits was valued positively; like the biblical King David who saved his people by defeating the giant Goliath, Maurits would defeat the godless giant Spain and thereby save the Dutch. David and Maurits were compared in an implicit but barely concealed manner. Readers would have had no difficulty arriving at this interpretation, since the printed version of the play was dedicated to Maurits and it had been written for a competition in which the question set by the Schiedam chamber for entrants to answer was:

What honour belongs to a Prince who engaged his enemy

Triumphed by force of arms and brought peace to the community? ${ }^{85}$

The parallel between David and Maurits is reinforced by paratextual means: a choir of Israelite women sings a song of praise to David in the style of the Wilhelmus. ${ }^{86}$ Van de Wael was showing very clearly which side he was on and was attempting to identify his personal preference with the general interest.

Duym's reference to the 'Spanish Inquisition' and Van de Wael's reference to the myth of a Dutch Israel point to another important

\footnotetext{
${ }^{83}$ See, for instance, Groenland, 'Toneel als pamflet?'.

${ }^{84}$ See Bloemendal, 'König von Gottes Gnaden?'. For Van de Wael see (for example) Van Dixhoorn, 'Liefhebbers van de redekunst', especially pp. 27-28.

${ }_{85}$ 'Wat eer den Prins behoort, die syn vyandt bestrede, / Met Waep'nen overwon', en braght 't gemeent' tot vrede?'

${ }^{86}$ The Wilhelmus, which has now become the national anthem of the Netherlands, was a popular Orangist song created by an anonymous poet in the tradition of the rhetoricians and for or in the circle of William of Orange. There is debate as to its author, the time of its origin and the aim of the song.
} 
function that literary texts fulfilled in the formation of opinion. They helped to develop and disseminate frameworks, templates and stereotypes by means of which an interested public could interpret the world, explain social developments, identify standpoints and groups and decide which party they preferred. Since it was difficult for governments to estimate the effects of such texts, it is conceivable that in some way or other they took account of publicly expressed views like these in deliberations at the highest level. Moreover, the political elite was itself part of a public that read, listened and conversed. Its members could therefore be directly addressed and influenced by arguments and formulations, and by the climate of opinion, fictive or otherwise, represented in literary works.

The fictive public conjured up here is a real factor in the process of opinion-formation because majorities have an important legitimizing and moralizing function and contribute to social pressure. Views that are successfully presented as those of 'the public' may very well correspond to those of an actual majority-but not necessarily. The fictive public that is made visible in public exchange and 'observed' in private therefore complicates the dynamics of public opinion considerably. ${ }^{87}$ We believe that historians should be aware that this fictive public existed even before 1700 and was powerfully portrayed in literary works in particular, whether they were disseminated in a written form or by being sung, recited or acted.

\section{AN APPEAL IN RHYME TO THE PEOPLE OF MECHELEN}

While in stage scripts like those by Jacob Duym and Job de Wael various ideas could be weighed up at the same time, in their incisive ballads, pointed songs, didactic ballads and other forms of verse, authors often took a more clearly defined stance. A manuscript from Mechelen, now in the British Library, consists of a collection of documents on how a 'revolt' arose against the 'natural prince' ${ }^{88}$ Additional coherence is given to this collection of political and governmental documents (letters, placards, edicts and petitions) by the poems interpolated between them, such as a pasquil and a ballad from 1567, which comment upon

${ }^{87}$ Compare Mah, 'Phantasies of the Public Sphere'.

${ }^{88}$ British Library, Additional Manuscripts, 18, 291. Copies of official letters and papers relating to the War of Independence in the Netherlands from 1566 to 1578. 
events. ${ }^{89}$ One of these poems entitled Advertissement ende loffelycke vermaninghe aen die goede catholycke borghers van Mechelen gedaen doer medelyden vanden zeer vermaerden ende oude Philosooph Pasquil van Roome (Warning and praiseworthy exhortation to the good Catholic citizens of Mechelen given out of sympathy by the very illustrious and old Philosopher Pasquino of Rome), rants and raves against the geuzen (the 'beggars' or rebels) and the calfsteerten ('calf-tails' or Calvinists). The Catholic citizens of Mechelen are taken to task, and in doing so the writer examines various ideas that must have been doing the rounds in the town (or at least, the writer believed them to have been). In the process he explains to his fellow citizens why, in his opinion, they did not make a stand against the destroyers of images, even though he believes the iconoclasts were nothing more than a small 'bunch of rogues', and despite the fact that the Catholics were vastly in the majority. The Advertissement is a powerful plea to take up arms to defend the church and the king.

The Advertissement, which is signed 'Schellart Willet Doorgronden' (roughly Schellart Wantsto Fathomit), was probably never printed. The warning was very likely meant to be read or heard by the Catholics of Mechelen and it may have been read out in company or circulated in manuscript. ${ }^{90}$ By analyzing the outbreak of iconoclasm in Mechelen in 1566, a countrywide phenomenon known as the Beeldenstorm, it attempts to rouse the Catholic population into taking action against the beggars when necessary. The author presents the Catholics as people who think and act collectively and can be duped, convinced by arguments, held responsible, and called upon to take action. In short, Schellart addresses the Catholic citizens of Mechelen as a moral body.

${ }^{89}$ The term pasquil or pasquinade refers to an anonymous lampoon, often in rhyme. The pasquil takes its name from an ancient statue that was discovered during excavations in Rome in 1501 and freshly erected. Rome's residents started to hang anonymous Latin verses on it.

${ }_{90}$ E. van Autenboer, 'Een pamflet over de Mechelse beeldenstorm. Overdrukje Mechelse Bijdragen (1949)', refers to a Schellart-collection whose whereabouts were unknown to him at the time. With thanks to Prof. Judith Pollmann (Leiden) for this reference. It can now be ascertained that this collection is identical to the Papemanuscript which he also cites, and is the one now held in the British Library. Autenboer has edited the poem in a version from the Mechelen city archives that is a transcription from the manuscrpt now in the BL. Interestingly, Autenboer also refers to a list of books confiscated in Mechelen in 1568 containing a 'Pasquile addressant aux bons et catholicques bourgeois de Malines'. 
Schellart deploys literary resources to deal with a public issue. ${ }^{91}$ The letter in rhyme, supposedly written by the Roman philosopher Pasquillus (known to the English-speaking world as Pasquino), broaches what was for Catholics a pressing matter, defines the problem, treats the arguments, rebuts objections, informs the audience, and tries to convince people and even prompt them to act. So the Advertissement should be seen as part of a social debate. Texts like this pasquil, once in public circulation, fulfilled the same function in the public sphere as printed pamphlets and tracts, which were on the rise from the 1560s onwards. Until well into the seventeenth century, literary genres which were developed in an oral and performative context and then appeared in print, including fictional dialogues between allegorical protagonists championing specific standpoints and all kinds of rhymed pleas, commentaries and attacks, continued to lend form to the public exchange of ideas.

One complicating factor is that not all extant opinion pieces and written arguments were intended for public consumption, whether by means of handwriting, printing, performance or recitation. Works that were so intended (which we should probably assume to be the case with the Mechelen text) may have remained in portfolio or have reached only a very small group. Even so, they represent vestiges of individual opinions on arguments about general issues, or ways found by individuals to deploy those arguments. In this sense too, a text can be used as a source for historical research into public opinion. The Mechelen example also shows very clearly how, in a literary work with fictional elements, the fictive public can be given a definite shape (in this case presented as a majority that allows itself to be 'captured' by a minority) and called to account, fiercely criticized and urged to act.

\section{THE FUNCTION OF LITERARY TEXTS IN PUBLIC OPINION: A MODEL}

It should in any case be clear that literature, in whatever precise way we use the concept and however broadly or narrowly we define the term, has a hand in the process of forming public opinion and indeed the formation of a public. Literary texts can do this in various ways.

${ }^{91} \mathrm{He}$ was concerned about a problem (the supposed passivity of the Catholics of the Low Countries), which still occupies the minds of historians today. See Pollmann, 'Countering the Reformation in France and the Netherlands'. 
They can air specific opinions and so, as trendsetters, put specific matters on the agenda, or, as followers of a trend, put a given consensus into words in specific circles. A literary work can reflect the opinion of a single individual or a small group, and at the same time it can claim to represent the opinion of a larger group or groups (the mouthpiece function). In the early modern Low Countries, authors could readily deploy literary works, since they were usually operating within local communities, the chambers of rhetoric, where specific topics were discussed during meetings. The chambers in turn were in contact with other chambers, so that supra-local and supra-regional networks developed. Furthermore, the rhetoricians were in contact with other groups in the cities, such as printers and scholars, and with all kinds of other social groups, so that specific ideas could be handed on via their own networks as well. Gradually, therefore, through a combination of formal and informal circles, a well-informed public of 'right-thinking' citizens positioning themselves as moral guides of the community came into being. Humanist scholars who wrote and taught in Latin were also part of it.

Literary works could be deployed alongside this kind of public discussion. They were written and read, but above all spoken and heard and performed and watched. This often happened in consultation with local or supra-local authorities but also independently. The rhetoricians sometimes presented themselves as representatives of the government and actively contributed by producing plays, ballads and tableaux vivants at the Blijde Inkomsten (the Joyous Entries or first official visits of new rulers), but they were just as likely to express direct or indirect criticism (especially in songs and ballads) of the government, the church and its representatives, the community and dominant beliefs, religious or otherwise.

If an opinion is cast in a literary mould, this affects the manner in which we need to study it. The creation of a literary work requires such mental effort, such skill and such knowledge (of other literary texts, for example) that the opinion or opinions contained in it-in literature various opinions can of course be expressed alongside each other or in combination-are shaped, refined, and altered during the creative process.

In this way, literary texts can open minds to varied possibilities that are closed in reality, to all kinds of openings for change or indeed for stabilization. They can do this by means of their content, but sometimes the writing and publishing of a literary work is in itself a statement. The French Jesuit Nicolas Caussin wrote his Latin plays 
about biblical subjects and the lives of the saints at a time (the early seventeenth century) when the Jesuits in France were in an awkward position: they were regarded as critical intellectuals and as such their movements were restricted, but he was thereby able to demonstrate the vitality of his order. ${ }^{92}$

Literature shapes public opinion in another way too. It offers all kinds of narrative strategies, rhetorical devices and basic plots within which events can be recounted and interpreted. ${ }^{93}$ In other words it provides an arsenal of media techniques and a repertoire (allegory, dispute, conversation, oration) that can be deployed to influence the public debate. Literature therefore enables others, including those outside the formal public sphere, to follow an author's example and state their own opinions more forcefully.

Up to now we have identified seven functions of literary works in the process of forming public opinion. They can: 1) put something on the agenda; 2) announce, confirm or contest specific opinions and add arguments to a debate; 3 ) be used for instruction, for the provision of information, and to raise the level of knowledge of the public; 4) serve as a civilizing tool and equip citizens and others to express their opinions effectively in words; 5) assist in the formation of groups (as did psalms, martyr songs and rebel songs); 6) be deployed in a process of self-fashioning and self-presentation to become a leading opinion maker; and 7) be used to prompt people to behave or take action in a certain way.

Through the use of dialogue and debating techniques, many early modern literary works also made the social debate, its main themes and arguments and the main players within it visible to a broader public. Literary culture can be seen as a breeding ground for ideas in the sense that in early modern texts boundaries are often explored (and regularly transgressed). Authors of literary texts often experimented with forms and viewpoints, while ideas from other circles or other regions were adapted for local voices through local literary works. Conversely, local voices could be adapted for inclusion in Latin texts aimed at an international audience.

\footnotetext{
92 See Chevalier, 'Le châtiment de la démesure: les tragédies bibliques de Nicolas Caussin' and Valentin, Les jésuites et le théâtre (1554-1680), pp. 489-95.

${ }_{93}$ Compare Fox, 'Rumour, News and Popular Political Opinion', which points to the impact of basic plots disseminated through popular literature on the political imagination of the British public.
} 